\title{
Labelle: Funk, Feminism, and the Politics of Flight and Fight
}

\section{Francesca T. Royster}

For now he knew what Shalimar knew: if you surrendered to the air, you could ride it.

Toni Morrison, Song of Solomon

Flyyyyyy!

Patti LaBelle, "Somewhere over the Rainbow"

\section{Part I: Flight_-Breath, Movement, Elsewheres}

Labelle, the powerful funk/rock/soul group that performed and recorded from 1971 to 1977, had the power to shake up the room. Make the walls thump with their voices. Lift folks up till they soar. On a 1975 appearance on Soul Train, at the height of the group's popularity, the audience watches transfixed, forgetting to pose. Listening, they move together, individuality somehow melded into one more coordinated body. The bass thumps in their chests and carries them out and onto the dance floor, and we, too, feel the beat deeply. It carries even thirty-five years later. These are not some demure girl group. These are some kind of funky jungle birds, soaring, flying over the audience with their voices, giving them chills.

Within moments of constraint, often linked to the material world of sexism, poverty, and loneliness, we find a consistent sonics of flight and transcendence 


\section{Francesca T. Royster}

in 1970s R\&B/ funk/rock trio Labelle's music and performances. We hear the sonics of flight in Labelle's voices: Patti's long-held, soaring opening notes, the use of Sarah and Nona's background voices to circle, support, and uplift, the driving use of repetition and improvisation in the songs' endings - all aspects of virtuosity, an African-derived aspect of the jazz aesthetic. In Labelle's distinctly Afrofuturistic and feminist work, the black female body itself becomes a technology for flight. As Mark Dery defines it in his influential essay "Black to the Future: Afro-Futurism 1.0" (Dery, 1995), Afrofuturism is the self-conscious appropriation of technology in black popular culture in order to think out problems of imaginative freedom in the past, present, and future. We might think of this technology in familiar terms - images of space travel, computer enhancement of voice like vocoders - or in less obvious ways - the African drum, the phonograph, the microphone. Labelle's use of voice, as well as rocking funky dance, combined with incisive lyrics bring to Afrofuturism a black-feminist informed critique of race, sexuality, and gender. The technologies of their highly theatrical performances, including elaborate stage shows and costumes - and not the least, the microphone - make heightened use of the black body, bringing to the fore its survival and flourishing. At the same time that Labelle makes outrageous and amazing use of technologies, they could not do so without the body itself - the body's movements, its sensuality, the body's breath as it lifts others and sends them into flight. We see in Labelle's vocal and dance performances the ability to transcend the merely human toward the spiritual. Labelle uses these powerful tools to move across the constraints of genre, and to push past racialized codes of gender, drawing from the styles and histories of the past, and envisioning a freed-up future for its audiences.

In many ways, Labelle's ability to capture these moments of flight come from the hard work and insight from a career of struggle and deep immersion in the business of making music. Interviews with the group reveal a foundational sense of neighborhood and family for each of the women, but also experiences of struggle and risk: childhood poverty and violence for Hendryx, losing family members to cancer and diabetes for Labelle, and for all three, navigating the often financially and emotionally exploitative aspects of the music business, handling racial segregation on the road, and the sometimes sexism of the chitlin' circuit.

Patti LaBelle, born Patricia Louise Holte on May 24, 1944, began singing at age fourteen, at the Beulah Baptist Church, where she soon began garnering solos. She formed the Ordettes, her first group, in 1958, where she was joined by her future Labelle partners, Sarah Dash and Nona Hendryx, in 1959. Daughters of the Black Migration, like Patti, Dash and Hendryx were both born and raised in Trenton, New Jersey - the town where P-Funk's George Clinton was also born. Sarah Dash was born October 9, 1944, and Sarah on August 18, 1945. The three have performed together ever since the Ordettes, signing on with Blue Note Records as the Bluebelles, along with future Supreme Cindy Birdsong, earning their first hit, with "I Sold My Heart to the Junkman," touring 
the chitlin' circuit and eventually becoming the "Sweethearts of the Apollo," featured as a group and also backing James Brown there. Struggling with the departure of Cindy Birdsong, and with changing musical tastes, the group appealed to Vicki Wickham, a fan of their music and producer of London's Ready, Steady, Go and The Sound of Motown. Wickham saw in the Bluebelles a chance to take the powerful sound and countercultural feeling of British Invasion acts of the Rolling Stones and the Animals, to provide a fresh venue for the strong voices of the Bluebelles. Rechristened as Labelle, and especially with the help of Nona Hendryx's socially conscious lyrics, and later, Larry LeGaspi's outof-this-world costumes, Labelle pushed previous codes of black respectability, bringing eroticism, social critique, and gospel spirit to a sound somewhere between the cracks of rock and soul. This was especially captured in their live performances. Before its break-up in 1977, Labelle released seven albums, including Nightbirds (1974), their best seller. "Lady Marmalade," which appeared on Nightbirds, was the number one hit of 1975, according to Billboard magazine. The group was never able to match the commercial success of Nightbirds, though many songs enjoyed strong critical success. Gonna Take a Miracle, their 1971 collaboration with folk/soul singer and songwriter Laura Nyro, still appears on many critics' top-10 album lists. The group disbanded in 1977, each creating solo careers, and in 2008 the group made their reunion album, Back to the Future. The album, co-produced by Hendryx, Philadelphia soul creators Gamble and Huff, Kit Lambert, and post-soul mavericks Lenny Kravitz and Wyclef Jean, encompasses the edgy, fun, and futuristic spirit of their earlier work.

We can see Labelle's ability to harness the technologies of microphone, stage craft, and space, to move their audiences to new ways of thinking and experiencing their own bodies, in Labelle's history-making October 6, 1974, performance in New York City's Metropolitan Opera House - the first time a black act was invited to perform. In her 1996 autobiography Don't Block the Blessings, Patti LaBelle gives a vivid description of this performance. She describes the group's legendary entrance:

Somebody said we looked like African goddesses ready for some erotic ceremony. The gold curtains behind the band opened to reveal Sarah, her back to the crowd, standing atop a staircase wearing black feathers everywhere. The crowd stood up and cheered as she turned to face them and slowly descended the stairs. As she walked she was singing Nona's composition "Nightbirds" and the audience went wild. The crowd had barely settled back into their seats when Nona came out dressed in a form-fitting white spacesuit with silver studs at her breasts and crotch. On her head she wore a huge white feather headdress, and she too began singing "Nightbirds." Once again, the crowd was on its feet. When 
the cheers died down, the audience saw what one writer described as a "glowing orange bird goddess descending from the ceiling." It was me being lowered to the stage inch-byinch by invisible strings and wires, my arms stretched out to showcase a twenty-foot train of black and orange feathers. When I touched down, I dropped the feathers to the floor to show the copper spacesuit I was wearing underneath. It was pandemonium. (LaBelle, 1996, 179)

This moment of transcendence is enabled in part by the setting - the Metropolitan Opera House already rigged for highly theatrical fantasy. But key, too, for this moment of flight is the mutual power of the performers and audience. In the advertisements for the show, Labelle encouraged the audience to come wearing silver. The audience took this command and ran, or rather, flew with it:

People paraded up the Met's red-carpeted white marble stair wearing silver from head to toe. Silver hats, silver skullcaps, silver eyelashes, silver Afros, silver capes, silver jumpsuits, silver body paint, silver Christmas tinsel, silver studs spelling out Labelle. I even saw a silver jockstrap. The crowd was truly colorful. And they came ready to be part of the show. They brought tambourines and maracas and brought silver whistles that were sold outside for a dollar a pop. Hundreds of people had to be turned away at the box office because we sold the place out. (LaBelle, 1996, 177)

Reviewers of the performance at the Met describe audience members dancing in the aisles, reaching out for a touch, or even stealing a touch or a kiss. Likewise, Melody Maker reviewer Steve Lake describes Labelle's wowing 1975 tour to Europe and their powerful effect on both black and white members of their Dutch audience: "As Labelle winds it all up on stage with a rapid encircling of the auditorium, banging cowbells and tambourines, they finally bring the Dutch audience to their feet, the black contingent dancing and shaking huge fizzled bouffants" (Lake, 1975, 23). Labelle's powers of transcendence come from a mutual relationship between performer and fan, a belief, a commitment to the importance of that moment. This also transcends live performance to include recorded music as it becomes integrated into everyday life.

Labelle's virtuosic concerts, televised stage performances, and recorded performances demand their listener's attention. There is both a physical and ethical command for community participation and exchange. In my experience, it is virtually impossible to listen to Labelle without clapping, singing along a snatch of remembered lyrics, moving around the room, practicing a shimmy. "More! More! More!" Patti cries on the 1975 live recording of "Lady Marmalade," pushing herself, pushing Sarah and Nona, the horns to rise with them, 
pushing us. This use of performative virtuosity for the sake of community engagement is grounded in African-informed performance aesthetics. According to Omi Osun Joni L. Jones, in the African jazz aesthetic that we hear in funk as well as jazz, "it is an individual's responsibility to bring forth her specific and idiosyncratic self into the world" through "vocalizations, the gestures, the thinking, and the beauty" honed through repetition and virtuosity (Jones, 2010, 6). Patti LaBelle's voice often pushes past the edges of the song's traditional structure, pushing the boundary too, between performer and audience. As a trio, the group brings its listeners high and low, Hendryx with her "bone rattling" bass (Lake, 1975, 23) and with Dash's soaring harmonies.

Labelle's performances include a strong sense of movement to contribute to its aesthetic of flight, including literal flying, as well as rising from the bottom of the floor, vogueing, miming, shaking, strutting, shimmying, cha-chaing, and other forms of dance.

Labelle's costumes, too, suggest a kind of freedom of motion: the ability to change selves, move between eras and geographic locations, and create new ones. Patti wears a satin robe that is part-gospel choir robe, part-spacesuit, part kimono. She is and will always provide the gospel grounding of their sound, her soaring voice, her theatricality, her pushing beyond the limits of the body through her voice. Sarah Dash's voice is precise sweetness and also sensuality. In their 1970s performances, Dash is often the one wearing the least: a silver Dixie cup bikini, silver halter and shorts, or a feather skirt with thigh-high slits. She represents the insistence of black feminine body, claiming its space. Nona Hendryx is glitter and also self-reflection, the reflection of a future self. She wears a leather aviator's cap embossed with mirrors. Her feathers even come with mirrors. Hendryx, inspired by countercultural writers like Gil ScottHeron, Nikki Giovanni, Henry Miller, and Angela Davis (Powers, 2008, E2), pens many of Labelle's most revolutionary songs, gritty social justice songs like "Are You Lonely?" and "Who's Watching the Watcher?" Visionary songs like "Phoenix," "Space Children," "Nightbirds," and "Chameleon" that offer images of rebirth and flight that encompass personal journey and collective identity. "We must raise ourselves much higher," Hendryx tells the Space Children, the "universal lovers" in her audience.

Unlike some forms of futurist art and thought, Afrofuturism is never fully disconnected from the embodied histories of slavery, with its experiences of labor, pain, as well as social death. Afrofuturism can be seemingly paradoxicaloffering modes of transcendence toward a future without ever fully escaping that past - rethinking the definitions of the human while always mindful of past denial of full humanity for black people. Indeed, much Afrofuturism takes as its grounding not just an understanding of past histories of black bodies in pain, but an overstanding of it, offering a space for rumination, creative rethinking, and ultimately, liberation. As critic Alondra Nelson puts it, Afrofuturism "looks backward and forward in seeking to provide insights about identity, one that asks what was and what if" (Nelson, 2002, 4). 
Perhaps the ideal way of capturing Afrofuturism's paradoxical rumination of the past through embodied transcendence is funk, which depends on both the meditative powers of repetition, what Baraka calls the "changing same," and the tangible presence of sweat, muscle, heat, and, yes, smell and all of those other pleasures of the sensual and sexual. This transcendent funkiness, one that offers "fight" or engaged struggle with the past, along with the "flight" from it through soaring sound, is one of Labelle's most important and underestimated contributions to the genre of funk.

The idea of flight - of transcendence while still being distinctly in the body-becomes embedded in Labelle's iconography, as we see on many of their albums' cover art. On their first album, Labelle (1971), the three are playing on gymnastic rings, each in a different pose of suspension. They're wearing little jewelry and their faces are unmasked, wearing little makeup, a dramatic contrast from the Afrofuturistic high drama of their later albums. Each woman is wigless; Nona and Patti are wearing simple, well-shaped Afros while Sarah's hair is gently curled. The photos are childlike, playful, fresh, and maybe also a little kinky. But they also speak to the promise of their gravity-defying voices, notes that will turn themselves and you, the listener, upside down. This spirit of defiance and transcendence would be conveyed visually and sonically in their future albums. The cover of Nightbirds (1974), their salute to "Creole ladies of the night," in Patti's words captures the women in motion-Patti with arms flapping in the background, Nona and Sarah in the foreground, heads blurred in movement, arms back as if to increase their velocity. In Phoenix (1975), the women are dazzling in angelic choir robes, heads uplifted to the skies, three in-flight doves. Chameleon (1976), the trio's final album as a group, shows the three with their backs to us, most of the album taken up by blue sky. They are visionaries; they have seen what we might also see in the future. To further this effect, Nona wears a funky silver turban-come-space helmet, an intergalactic Eartha Kitt. On the back of the album, we see the three women from the front, arm in arm, open smiles, laughing.

This is distinct from the aesthetic of the girl group, and its performance of demur femininity. Matching, wigged and sexually domesticated and contained, girl groups are often seen as the protégés of others: Phil Spector, Berry Gordy, Harvey Fuqua, and Quincy Jones. Labelle came out of these earlier experiences of the hard working girl groups, laboring in the chitlin' circuit and eventually at the Apollo, singing background to James Brown, still searching for their own sound, look, and vision. ${ }^{1}$ As Sarah Dash tells her audience in a 1990 New Music Seminar, "When we were Patti LaBelle and the Bluebelles, we all wore the same wigs, the same dresses, and the same heels. Then we came together saying it was time to break this mold. Why do black women all have to look alike because they're singing together? .. . We wanted to change the whole image and the whole mentality of how black women were supposed to represent themselves in this industry" (quoted in Garr, 2002, 164). It was the patriarchal strictures of the girl group, the propriety of those matching shoes and synchro- 
nized voices, the structural and generic constraints-all these inform the trio's reinvention and flight, from Bluebelles to Labelle.

In the effort to move away from their former girl-group style, in Larry LeGaspi, Labelle found a look that visually expressed their vision for the future that is queerly and thrillingly embodied. LeGaspi-outrageous fashion designer, Labelle fan, and king of sparkle - designed Labelle's costumes for live performances and public appearances on Soul Train and The Midnight Special, as well as her later work on Broadway. He would later go on to design similarly Afrofuturistic stage costumes for Kiss, Funkadelic, Divine, and others. LeGaspi, gay, Puerto Rican, and from working-class roots, saw the potential in the disco as a space for comfort and home as well as outrageousness. "Disco is the one safe place that people can put on my clothes and really feel comfortable," he once said. ${ }^{2}$ LeGaspi's work embodies an affinity between gayness, folks of color, and futurism - a yearning for an elsewhere, but also innovation.

With the help of LeGaspi's look, Labelle's performances present a highly theatrical presentation of sexual fantasy linking the past to the future: chain mail loincloths, flight helmets, handcuffs, long dangling star and moon earrings, silver space helmets, silver spacesuits, silver eye shadow and face glitter, silver and more silver. There's a global as well as an intergalactic aspect to these costumes, referencing Carmen Miranda's ruffled sleeves, Amelia Earhart's doo-restraining flight cap, African masks, Hindi wedding makeup, the sweeping fullness of a flowered kimono sleeve, as it may or may not have been worn by Diana Ross in Mahogany (1975). Sometimes their costumes cross the lines of human, animal, and goddess: leather, ermine, feathers dyed orange or midnight black or blinding white in the form of skirts, boas, headdresses, bras, all enabling the mysterious ability to fly. For Patti LaBelle, this spectacular approach to costuming their bodies is purposeful. In a 1975 interview with Rolling Stone's Art Harris, she says:

Some people have to see first. They might see a poster of these three crazy-looking ladies and say, "Wow. We should see what they're doing. Maybe they're The Supremes." But we're singing material that we want to sing-but people won't listen if we speak like human beings. We have to be raving animals, talk loud and look crazy. So after they look at us, they might listen. (Harris, 1975, 44)

In the group's theatrical style as well as in their lyrics, they are revising sexuality and using their bodies, combined with their voices to open up new possibilities. In Don't Block the Blessings, Patti very consciously uses the term "drag" to describe her approach to clothing. She says she was right on board with the band's move from a rock aesthetic of scruffiness in Labelle (1971) to a more fabulous futurism. She writes, "I melted right into that drag. I am the 
original drag queen. Whenever Larry brought his sketches by, I thought, 'This is me, baby!'” (LaBelle, 1996, 172).

Labelle's theatricality was both a sign of the group's queer aesthetics and a sign of the times, linked to developments in glam rock, and the subcultural genre-pushing of funk rockers like Funkadelic and Sly and the Family Stone. Funk legend George Clinton describes this cultural moment to Ann Powers in a 2008 interview:

"Alice Cooper and David Bowie, they were doing their thing," Clinton said by phone from a spot on his current tour to promote his new project, the doo-wop flavored George Clinton and his Gangsters of Love. "That whole period, everybody was going for theatrical rock. So we just said, 'Let's go all the way with it. Let's do it all.' That's what we did, and that's what they were doing too." (Powers, 2008, E2)

Labelle shares with Clinton's Parliament and Funkadelic an interest in the performing black body as a space and conduit for transformation and movement, whether through the ministrations of Doctor Funkenstein or Bootsy's relentless on-the-One bass. Both Labelle and P-funk use their music to both dramatize and explore sexuality and pleasure, sometimes using theatrical personae. But the difference that Labelle makes is the centering of black female experience. So while Parliament and Funkadelic offer an almost exhaustive list of sexual desires, practices, and experiences to shape an often gender-bending, and otherwise nonnormative black masculinity in their music and performances (from spanking to cross-dressing to anal sex), Labelle instead centers and performs a critical and liberatory black femininity that is both forward and backward looking to past struggle. ${ }^{3}$ Might Lady Marmalade's silky skin, "the color of café au lait," not remind us, for example, of the deep roots of New Orleans' trade in light-skinned women as objects of pleasure, from slavery to the present? And songs like "Nightbirds," "It's Been a Long Time," and even "Dancing in the Streets" (performed in collaboration with Laura Nyro) offer a promise of release from interpersonal and social constraint, looking, at the same time, over one's shoulder.

In addition to sexual freedom, Labelle performs creative freedom by moving across genres, to push past racialized codes and rules of style to try on multiple styles and to create fully formed characterizations in their performances, drawing from the styles and histories of the past, and envisioning a freed-up future. Music critic Kandia Crazy Horse praises Labelle's performance of black female creative freedom, in comparison with more recent $\mathrm{R} \& \mathrm{~B}$ and soul artists:

In one episode of Soul! Labelle had the freedom to leap from a cover of their friends the Rolling Stones" "Wild Horses" to their own gospel eros "Morning Much Better" and succeeded 
in the mass market to the point where they could perform the polemical "What Can I Do for You?" without fear of censure on rock TV that's geared toward the dominant culture. It's baffling that with all their market opportunity, lux lifestyles, bleached demeanors and hair exploited from even more disenfranchised Third World Women, none of today's prematurely crowned divas can offer nuanced, life-affirming art to rival the dark, sweaty, relatively gut bucket sisterhood of Labelle - only robot sexiness, oversouling and lyrical cynicism. (Crazy Horse, 2008, 28)

Kandia Crazy Horse sees Labelle's performance of invention and freedom as evidence of their Afrofuturism, their "terrestrial insurrectionism, extraterrestrial hope and yearning toward the cosmic eternal," ultimately affirming for their listeners the survival of the black body (Crazy Horse, 2008, 30). Likewise, the Black Rock Coalition, a collection of black rock musicians and other artists, cite Labelle, along with Sly Stone, Chuck Berry, and Jimi Hendrix, as chief influences in their own vision of artistic freedom and right to creative independence. In their 1985 manifesto, they reject "the demand that Black Musicians tailor the music to fit the creative straitjackets the industry has designed." 4

As I'll discuss below, Labelle, at their height, countered past restraints on black female sexuality and creativity, provided a strong critical "read" of white rock's history of appropriation without shutting the doors to collaboration and multigenre fluidity of sound, and commandeered the disco space as a place of community and spiritual renewal for multiple sexualities, races, and genders through the powers of theatrical performance that drew equality from gay spaces like the club, house party, and bath house, as well as from the black church.

Maybe this is why James Baldwin was said to be a big fan of the group. Both Labelle and Baldwin draw from these sometimes contradictory resources of club and church ${ }^{5}$ to imagine an elsewhere. As Jose Esteban Muñoz has written, queer utopic spaces such as those found in Labelle's performances help us imagine in moments of hopelessness "an escape from this world that is an insistence on another time and place that is simultaneously not yet here but able to be glimpsed in our horizon" (Muñoz, 2009, 1873). For Baldwin, such imaginings always butted up against the harsh material realities of racism and poverty in America. At the same time, Baldwin loved and needed music, parties, and good company. ${ }^{6}$ And Labelle, too, faced these realities in the form of a record industry that both feeds on the new while often smothering invention. Despite these constraints, Labelle sometimes managed to touch the sacred.

Bernice Johnson Reagon describes as "singing in a black style," in gospel and other forms of music, as bringing together one's own virtuosity and embodiment in the human struggle for transcendence: 
In singing in a black style, "You have to be able to charge the notes with feelings before the sound comes out of your body.... So you are not singing notes and tones, you are giving out pieces of yourself, coming from places inside that you can only yourself visit in a singing. It is having what is inside yourself ride the air in the song you are singing." (quoted in Bell, 1996, 2)

Reagon's quote takes the intangible notion of spirit, and brings out what is embodied and personal about it, as it exists in black music. What do we have inside ourselves but our memories, desires, struggles, energy, as well as our blood, organs, spit, and bile, the things that make us keep living and moving, the things that link us to other human beings, but also speak to our uniqueness. And it all starts with the breath.

Listen again to "It Took a Long Time" on Nightbirds (1974), and listen to the breath. The song begins with release. Patti sings in a quiet voice, gentle:

It took a long time to find this place.

It took a long time to see happy.

It took a long time to recognize your face.

It took a long time of running around.

Nona and Sarah circle Patti with small quiet breaths: "been a long time, been a long time," they sing. In the second refrain, as Patti tells us a second time how long it's been, she pushes air deep to sustain that word "long," coloring it with her past anguish, the blues still hiding somewhere in the corners of her lungs, maybe. She might have to bend her knees to get that deep, or raise a hand in testimony. But as she and Nona tell that story of waiting, of failing and then trying again, there is an opening that we can hear in her breath, in the quality of her notes, a progression of feeling that comes with repetition. She might be singing about finding a lover, about finding God, about self love, but she is also telling us at the same time about losing, and then releasing that loss, and we can hear it in her breath. She is telling us about grace, even as she takes flight.

\section{Fight: Sex, Gender, Disco, and the Possibilities of a Feminist Funk}

Rickey Vincent's cogent and powerful definition of funk, as "an aesthetic of deliberate confusion, of uninhibited, soulful behavior that remains viable because of a faith in instinct, a joy of self, and a joy of life, particularly unassimilated black American life" is right on target in terms of Labelle's visionary music and performance (Vincent, 1996, 4). It is a shame, then, that Vincent gives such minimal attention to Labelle's performances in his study. This reflects, unfortunately, a still consistent sexism that shapes the evaluation of funk 
music. ${ }^{7}$ In Funk, Vincent's analysis of Labelle is brief - sharing a single paragraph with the Pointer Sisters in his three-page subchapter, "Funky Women." He writes that while "Lady Marmalade" "blew the lid off of the standards of sexual innuendo and skyrocketed the group's star status," the band's "glittery image slipped into the disco undertow and was ultimately wasted as the trio broke up in search of solo status" (Vincent, 1996, 192). While Vincent rightly captures the social impact of the "Lady Marmalade" (elsewhere he calls it "scorching" and "another funk bomb!"), he underplays the group's impact as a whole, including the power of their lyrics, the strategy behind the spectacle of their performances, and the meanings that the group has played for their fans in shaping their consciousness. In this important transitional moment, in terms of race, gender and sexuality Labelle was especially important to black, Latino, gay fans and for women. Vincent's brief treatment of women in his otherwise persuasive work reflects a larger problem in funk discourse - one that marginalizes queer and women's consciousness and the role of that music can play in shaping a collective and transformative experience of funk. Perhaps this is symptomatic of the split between funk and disco that former DJ and cultural historian Alice Echols describes in her book Hot Stuff: Disco and the Remaking of American Culture, where disco is seen by some as artificial, feminine, and/or queer, and suspected of selling out, while funk is seen as innovative, authentically black, and masculine. Indeed, according to Echols, for both critics of rock and critics of funk, disco provided a problem of gendered inauthenticity:

\begin{abstract}
[A]s disco moved out of the underground and into the mainstream it became marked, even tainted, not just with 'soulless soul' but as girls' music. Although disco's prioritizing of the rhythmic over the melodic, its circular structure, and the sheer length of its songs actually put it at odds with pop music conventions, most rock n' rollers nonetheless viewed disco as the worst sort of pop fluff. The denigration of pop as sappy and nice (and feminine) and the elevation of rock as hard-hitting and risk-taking (and masculine) date back to the beginnings of rock. (Echols, 2010, 72)
\end{abstract}

Echols also suggests that as disco becomes more commercialized, the range of performative styles sought after by record companies, especially for female performers also narrowed (Echols, 2010, 78). So while the critique of disco becomes gendered and sexualized, deflecting the narrowness of the sound onto the fans themselves, the fears about formulaic sounds are not entirely unfounded. ${ }^{8}$

For at least the time that they were on the scene, for disco's fans, Labelle provided a soundtrack for genuinely funky cross-racial and cross class intermixture, at least in its ideal moments. Henry Edwards's 1975 article "The Street People are Taking over the Discotheque" in High Fidelity captures this sense of possibility of the disco as a space of interconnection: 
The music blares! The lights flash! And the packed room pulsates with energy and excitement. Crunched into Le Jardin, the trendy, funky basement disco club on Manhattan's West side are thousands of happy, seating, gyrating disco dance fans, sharing in common a passion for fancy stepping.... The polyglot assortment, even by sophisticated urban standards, consists of young whites and an equal number of blacks and latinos as well as many gays representing all three groups. (Edwards 1975, 56) ${ }^{9}$

Though Edwards also laments the ways that such marking and crafting toward racial crossing might affect the quality of the music itself - the loss of the "gritty" feel of R\&B for the "gobs of whipped cream" that "woo white fans without alienating blacks" - he holds up Labelle as a possible alternative future, one that offers grit as well as fantasy (Edwards, 1975, 58). Patti LaBelle tells Edwards, "We bring feeling to our music, tell stories of what life is and can be. . . Y You can feel us and you can dance with us. Audiences need more feeling than they've ever needed before. They need theater. We played gay clubs and loved it because gays are into theater. And now we're breaking big because we've learned to put on a show. Our audiences are a spectacle themselves, and we give them a spectacle in return" (Edwards, 1975, 58).

As recent historians of disco have documented, at their start, discos were powerful happenings where gay men of color invented and shaped the sound, dances, styles, and social practices. ${ }^{10}$ But less has been noted about women's role in disco, especially black women's place as both performers and consumers. In this next section, I'll explore more closely Labelle's productive use of the spaces between musical genres - disco and funk, rock and soul, gospel and $\mathrm{R} \& \mathrm{~B}$ - as spaces of creativity and critique.

\section{Fantasy and Grit: Labelle (1971), Nightbirds (1974), Sexuality, and Black-Girl Rock Critique}

In Rolling Stone's 1975 profile of Labelle, written at the height of their national popularity, printed in the margins in huge, squat lettering, is "ummm un aaah oh god Oooh, it's so good" - the sounds, presumably, of someone (Labelle? Listener? The interviewer?) reaching orgasm. This design is in keeping with the piece itself, which feature at its center a discussion of Labelle's sexual openness. In addition to the lettering, the opening pages features lyrics to the song "Lady Marmalade" and photographs of the group in their scantiest, most outrageous costumes. But what at first glance seems exploitative and stereotypical over the course of the article (especially because Rolling Stone often doesn't feature cover stories of black women) seems to be a strategy for an analysis of Labelle's embodied take on performance, and openness in talking about sex. 


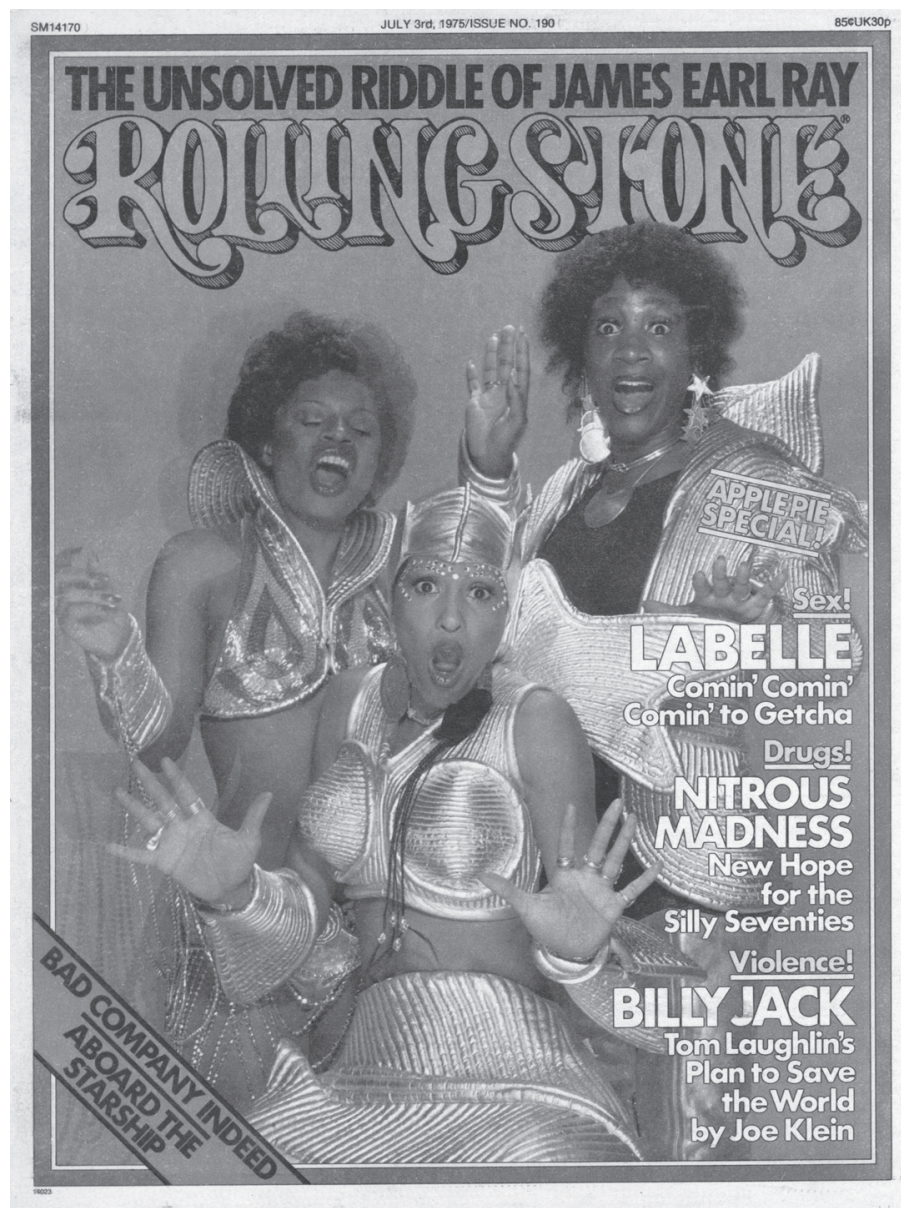

Figure 1: Cover of Rolling Stone, Issue No. 190, July 3, 1975 featuring Labelle (photo by Hiro) (the “Cover”). Copyright (C Rolling Stone LLC 1975. All rights reserved. Used by permission.

For example, Patti LaBelle describes the emotional power of performing:

It's like my husband. It's like I'm married to a million men and women when I'm out there. And when I'm married to a person, I give all I have. It's like a climax, and when the audience does it like they did last night in Atlanta, I come. When I came out during "Space Children," just standing there, the way they made me feel - that's an orgasm, to see people accept you right away. (quoted in Harris, 1975, 42) 
Patti makes no bones about the role of desire and sexual charge in her connection to her audience. She represents the mutual interdependence of performance as an embodied experience, which also involves vulnerability and connection. She continues this embodied discussion of performing, confessing that she often pees on herself when she gets going. (She also makes this joke in her autobiography.) "Yes," she jokes, "I mean Pampers on stage — or might as well! I'm going to start carrying a box with me because it happens a lot. And between that and my crying" (Harris, 1975, 42).

Later in the article, Sarah Dash is similarly uninhibited about the link between sexual release and singing and bodily fluids, even admitting that she can't wear tampons while performing in fear of losing them. But she also pushes the analysis to deepen it. She tells Harris, "I feel tears and a good hurt and a good pain. It's ritualistic, spiritual. When we recorded "You Turn Me On," I was howlin'. It was not just sexual, it's what life is about" (Harris, 1975, 42).

Has there been a clearer inheritor of the sexual frankness of Bessie Smith and the other blues women of the 1920s than Labelle? Labelle is noteworthy in not only telling stories about sex, but in making the act and pleasures of performing explicitly sexual - and then offering an analysis of it. Certainly performers like Millie Jackson, Etta James, Eartha Kitt, Donna Summers, and many others have made their sexuality central to their performance style, but few black women performers take up precious public space to reflect upon it - and it's a mark of a shifting era that Labelle had this space. We might think about this in terms of developments in black feminist work in this era, particularly around the issue of sexual freedom. This is the era of the sexual revolution, of course, but one more explicitly for white women. Erica Jong's controversial novel about women's sexual discovery, Fear of Flying, was published in 1973. Black feminist writings of this era, including work by Angela Davis, Michelle Wallace, and the Combahee River Collective, argued for the need for sexual agency for black women, often historically grounding their analysis in the experience of sexual exploitation during slavery. But negotiating the pressures of black respectability and homophobia often left little room for discussions of sexual pleasure, even among black feminists. Closest to Nightbirds and Labelle's other work in spirit is Ntozake Shange's choreopoem For Colored Girls Who Have Considered Suicide, which rocked the scene in 1977. Labelle was in fact on the cusp of an opening up of spaces for black women's sexual expression: Alice Walker's The Color Purple, published, in 1982, notoriously created a public outcry in the black community in its depiction of Celie's sexual discovery, and in particular, her lesbian desire. Indeed, in the 1980s, an outflow of black and other woman of color feminist LGBTQA writing dramatically shifted the conversation about sexuality, identity, and pleasure, including Audre Lorde's Zami: A New Spelling of My Name, and Barbara Smith's anthology Home Girls: A Black Feminist Anthology, both published in 1983. These works, together with music like Labelle's, were providing new spaces for black women to reflect on their sexual pleasure and the politics of that pleasure. 
In 1970, in the last days of the Bluebelles, the group faced the struggle of finding an audience lit on fire by the British Invasion. In an effort to create a more cross-racial audience, collaborating with producer Vicki Wickham, the group underwent a transformation in name, as well as image. Wickham "saw Labelle as three black women singing about racism, sexism and eroticism" (LaBelle, 1996, 154). Wickham's vision of Labelle was to recreate the group as not only a female Rolling Stones, but a black girl's Rolling Stones: taking back the spirit of the blues men in their rebellious and explicit talk about sex, men mourning and bragging and crying out, and combining it with the confidence and outrageousness of the Stones' white bad boyhood. Of course, as veterans of the Beulah Baptist Church, black nightclubs, the Apollo, and the chitlin' circuit, these were women already steeped in the tradition that the Stones were just learning, and they knew and understood the interconnections between sacred and profane in the blues. They understood the funky power of gospel, and so what Wickham shaped was a group that caught our attention, but what we heard was something both new and old. This was Afrofuturism, in both the spaceagey suits and raucous revised sexuality, but also in the spirit — the ability to capture transform, create church in their audiences.

In a move risky to its crossover project, Labelle's first album reads and listens as a direct rebuttal to the gender politics of those bad boys of the British Invasion, from "Under My Thumb" to "Some Girls." The album is also a sonic rebuttal to these and other white boy rockers in its centering of black female vocal power, used as background singers by white rockers on many rock songs, including the Stones' "Honky-Tonk Woman" and Lou Reed's "Take a Walk on the Wild Side."

To add further complication to their work, Labelle does so while also occupying and sharing the spaces with these musicians. Labelle opened and toured with the Stones, opened for the Who, and performed "Miss Otis Regrets" with Keith Moon cameoing on drums, accompanied by Elton John - all while sharing friendship and Patti's plates of home-cooked soul food in the bargain. In fact, Patti, Nona, and Sarah cite ongoing friendships with Jagger, Richards, Elton John, Pete Townsend, and other white rockers. ${ }^{11}$ So within their critique is room for collaboration and innovation.

That Labelle combined the tactics of black church and black feminism, along with their own original, and often queerly erotic theatricality, while also seeking white audience members was a risky move, and one that may have contributed to their being misread as a novelty (as in the Rolling Stone cover story) or underestimated in their political possibilities (as in their brief treatment in works like Vincent's book Funk). But it also resulted in powerful, and mutually empowering relationship between the group and their fans, past and future.

Labelle (1971) provides an excellent alternative view of black female sexuality from that reflected in the Rolling Stones' 1978 song "Some Girls" and especially the song's notorious line, "Black Girls just wanna get fucked all night"-with an emphasis on the "just" of that statement. While sexually 
bold, the speakers in Labelle's songs are emotionally complex and socially conscious. Sex is never separated from spirit, and this is guaranteed by the gospel sound that saturates the whole album.

"Morning Much Better," the opening song, features Bob Mann's rocking electric guitar creeping forward, something like what Black Sabbath might use. But instead of Ozzie's nasal paranoia, the song features the warm, funky, and strong voice of Patti, fortified with a gospel-influenced response from Sarah and Nona. The discussion of sexuality in the song is bold, the voice explicit, confident, unapologetic, but still lyrical: "I like it early in the morning with the sun up and the air so sweet." The speaker is telling her lover what she wants in bed - or more distinctly, "prefers"- a playful corrective. The "it" discussed is coyly never named, but it manages to get the point across by using a driving gospel sound at the end, giving it an orgasmic effect, ending with Patti's exhausted and satisfied "Oh Yeah." The song has the pace of a rollicking ride, but there's also a tone of tartness in the lyrics.

Reinterpreting the Rolling Stones" "Wild Horses," a little later on the album, the song starts on an energetic high note, rather than taking on the laid back, almost burned-out approach of the Glimmer Twins. In fact, the song follows a pattern of many songs led by Patti, starting out with a powerful, soulclearing, gospel-inflected opening note. The song must negotiate some of the bitter sexual politics of the song, cutting out the line "Graceless Lady," for example, and replaces it with a note of humbled self-knowledge:

\section{I know I've dreamed you a sin and a lie \\ I have my freedom but I don't have much time. \\ Faith has been broken tears must be cried \\ Let's do some living after we die.}

The help of gospel-inflected riffs on Gene Casey's piano, and the knowing mmmm hmmms of Sarah and Nona's background loop spins a much less exhausted, and more hopeful, compassionate feeling to the song. But there's also licks from a buzzy freaked-out electric guitar by Bob Mann, something like the Isley Brother's "Who's That Lady," haunting the song around its edges, a hint of past rock indulgences - and a way that the song also references the version that came before it. It doesn't want the Glimmer Twins to be an unrecognizable influence, but at the same time, it puts them in the background.

To be groomed as the Black Girl Rolling Stones would by necessity be a dynamic, even combustive struggle. This sense of struggle must necessarily be informed by the history of love and theft of black sound, the ways that rock music has decentered the experience of women in its past, and for the most part kept black women invisible, except only as sexual teachers, or knowing background singers. In the face of the casual racism, patriarchy, and the denying of female knowledge in rock music, embodied sound is a necessary bridge. For Labelle, performance becomes a way of capturing the attention of those who 
might not listen; it becomes a source of pleasure, mutual creativity, and community for its fans and for the performers, and ultimately it is a salve for past alienations - a way of coping with a world of contradictions.

By far the group's best-selling and most known album, Nightbirds (1974) focuses on the lives of women in particular, including the infamous "Lady Marmalade." Each of the songs captures the thoughts and feelings of their subjects and even "Lady Marmalade" insists on the complexity of their lives below the surface. In a 1975 interview, Nona Hendryx told Rolling Stone that she penned the song "Nightbirds" while thinking of Janis Joplin, as a kind of defense of her after reading Going Down with Janis and finding the book derogatory: "To me the book destroyed the illusion of her music. The song wasn't in answer to the book, it was just my own tribute to her," Hendryx says (Harris, 1975, 45). "Nightbirds" recaptures this magic, in a quiet, melancholy tune. And like the subjects on the rest of the album, the Nightbird struggles to maintain her sense of freedom and creativity, in the face of struggle: "she stores away nothing / tomorrow's a dream, running out of steam." Like Labelle themselves, the Nightbird's method of survival is to take pleasure and grace in her own ability to fly: "She touches down / just to feel her wings."

At first glance, "Lady Marmalade" is the story of the ordinary nine-to-fiver, known only to us as "Joe." It would seem to be his song, the story of his own sexual awakening at the hands (and black satin sheets) of Lady Marmalade. But this song is not really told from his perspective. More compellingly, we get the perspective of a chorus of sympathetic observers-Patti, taking the lead and supported by Sarah and Nona's memorable "Hey, Sister Soul Sister!" We learn about how this ordinary "Joe" is haunted and undone by the "creeping" memory of Lady after the fact, even after he has returned to his ordinary life. But the heart of the song is the description and voice of Lady Marmalade herself, as it is presented to us by the chorus, her "silky smooth" skin, "the color of café au lait." The chorus represents Lady's own voice, through that famous "love" call, interpreted as "would you like to go to bed with me," and as well as her additional descriptive, but not quite translatable taunts: "Getcha Getcha Ya ya dada / Mocha chocalata ya ya." This is the groove of the song, and so then we too are invited to put ourselves into the place of this soul sister. Rather than to distance ourselves from her, through the sheer force of pleasure of the beat, the catchiness of the tune and the bold attitude, we join in. Perhaps it was the pleasure of joining in with Lady, and becoming her in performance, that made folks uncomfortable. According to Rolling Stone, at the time of its rise up the charts, from 1974 to 1975, the song was the subject of a boycott by Mrs. Marvin Branham and a group of black mothers from the St. Theresa's Catholic Church, who said that the song "flaunts prostitution and is offensive to blacks." They hounded radio stations to stop playing the song and put ads in the papers to spread the word. Philadelphia school children were threatened with suspension for singing the song. Labelle was asked to alter the lyrics, changing "coucher" to "danser" on Cher's and the Mike Douglas shows, as well as television ap- 
pearances in Belgium and France (Harris, 1975, 46). Clearly, what was difficult about the song was not the mere acknowledgment of the reality of prostitution in New Orleans, just "Joe's" pleasure seeking, or the effect that Lady had on him, but instead, the effect that the song has on us, and the ways that it encourages us to take on Lady Marmalade's voice as our own. Especially toward the end of the song, "Lady Marmalade's" chorus, "Voulez-vous coucher avec moi ce soir," follows the gospel music structure of the "drive," where the music pares down to just the singer's voice and percussion, and in this space and through repetition, a place of improvisation can take place. In performance, it is a place of opening up, where the singers might leave the stage, move among and even touch the audience. In gospel, this moment is one of heightened emotion and also connection between performer and audience. ${ }^{12}$

Next on Nightbirds, "Lady Marmalade" is followed up by two social visionary songs by Nona Hendryx, "Somebody Somewhere" and "Are You Lonely?" "Somebody Somewhere" speaks of the need for social change, the need for someone who will "hear our cries for freedom" and to read "the writing on the wall" that "we aren't right at all." The song ends with an allusion to the second coming of Christ. "Be prepared," the righteous chorus of Sarah, Nona, and Patti sing, with three toots of the trumpet. "He's coming back." The song "Are You Lonely?" continues this critique, naming homelessness, and especially the poverty of unwed mothers. It does so from a place of compassion: "You've been wondering why the rain never stops." Put together with "Lady Marmalade," these first three songs first engage us in the lives of others and then offer compassion for their suffering.

The second half of the album offers a space for healing, transcendence, and futuristic alliance. "Space Children" further captures this feeling of an outsider "us," "universal lovers" who desire to fly high, but who must also stop to "check it out." And "What Can I Do for You?" is an anthem for understanding, peace, and empowerment and mutual uplift — to live beyond mere survival: "People want to live, not merely exist. ... We need rain, we need life. ... We need love, love, love." The questions, "What can I do for you" and "What can you do for me," exchanged back and forth, speak to the song's sense of community. On the dance floor, the song has had incredible power. David Nathan remembers the effect of this song on him when first initiated into the gays of color scene in Brooklyn:

I'll never forget the very day I arrived in New York for the first time ever, Tony, my former London roommate, who had moved to Brooklyn, took me back to his apartment and told me to take a shower and get dressed for a house party later that Saturday night. The crowd at the party was mostly black and gay, and was having a good time until "What Can I Do for You?" one of the standout tracks from Nightbirds came on. The place erupted! Everybody, including me, was on 
the floor, boogying, hollering, screaming, and for those who knew the words, singing along. Labelle was the darling of the proud-to-be-black-and-gay crowd, and the group can do no wrong in their eyes. (Nathan, 1999, 232)

Nathan's description of the participation of the partiers is striking: not just excitement, not just dancing, but a near riot of enthusiasm. This song has the power to strike to the core of its listeners, and it seems that it goes beyond its powerful lyrics to the decisive, powerful delivery of them, each singer giving their all, pushing their voices to be heard. There is a collective experience of empowerment that the singers model, and it speaks to the link between church and house party, gospel music, and club. ${ }^{13}$

Labelle's success as a funk trio who created an original sound and performance from the cracks of soul, gospel, and theater, was sustainable only for a limited time. But their music continues to provide the soundtrack for us Space Children and other universal lovers who seek their uplift and vision.

\section{Coda: Songs of Flight and Fight}

In 1977, the same year of Labelle's final performances as a group, Toni Morrison published her novel Song of Solomon, a reprisal of the legend of enslaved Africans able to fly from bondage:

Some of those Africans thought brought here as slaves could fly. A lot of them flew back to Africa. The one around here what did this was this same Solomon, or Shalimar-I never knew which was right. He had a slew of children, all over the place. You might have noticed that everybody around here claims kin to him. Must be near forty families spread in this hills calling themselves Solomon something or other. I guess he must have been hot stuff or not, he disappeared and left everybody. Wife, everyone, including some twenty-one children and they all saw him go. (Morrison, 1977, 322)

In her novel she explores the masculinist vision of this legend. From her male protagonist, Milkman's point of view, flying is a newly discovered birthright. But for the women of the novel, the desire to fly is illusive. Sara Bird, an elder of the community, dismisses the story as an "old folk's lie." Hagar, Milkman's love, is never able to leave the ground, trapped by white-shaped notions of beauty and her own desire. Only Pilate, bootlegger and visionary, feared to be a witch, can fly "without leaving the ground." What of the women who were left behind, asks the character Sweet - a woman who we're told, like Lady Marmalade, exchanges her sex for money. "Who'd he leave behind," Sweet prompts the novel's hero (Morrison, 1977, 328). Through Sweet, and 
the other women, Morrison asks, what good is a politic of liberation that does not include and empower its women? Labelle offers an answer: Women are the voice, the visionaries, the ones who can see the link between sexuality and voice and transcendence, who embody the ways that funk music brings body and soul together.

\section{Notes}

1. For an excellent discussion of the pressure to be "good" and the sometimes oppressive aesthetics of the girl groups for women performers, see Buzzy Jackson's A Bad Woman Feeling Good: Blues and the Women Who Sing Them (New York: W. W. Norton, 2005), 191-93.

2. For a great discussion of LeGaspi's work, see unsigned, "Larry LeGaspi," in the blog Sparkle Army: http://sparklearmy.com/blog/?tag=larry-legaspi.

3. For more on the expansive possibilities of P-Funk's treatment of black masculinity, see my chapter "'Here's a Chance to Dance Our Way Out of Our Constrictions': P-Funk's Black Masculinity and the Performance of Imaginative Freedom," in Sounding like a No-No: Queer Sounds and Eccentric Acts in the Post-Soul Era (Ann Arbor: University of Michigan, 2013), 88-115.

4. Maureen Mahon, "Black like This: Race, Generation and Rock in the Post-Civil Rights Era" American Ethnologist 27, no. 2 (May 2000), 300. See also Mahon's book-length study of the Black Rock Coalition, The Right to Rock: The Black Rock Coalition and the Cultural Politics of Race (Durham: Duke University Press, 2004).

5. For a vivid and personal description of the powerful interconnection of club and church for black gay men, see E. Patrick Johnson's fine essay "Feeling Spirit in the Dark: Expanding Notions of the Sacred in the African American Gay Community," Callaloo 21, no. 2 (spring 1998), $399-416$.

6. A great image of James Baldwin, partier, is captured in a photograph with him and Lorraine Hansberry, getting down at what appears to be a house party, which recently circulated on the internet http://vintagenoire.tumblr.com/post/60452849088/secretsandsemantics-this-is-a-picture-of-james. Baldwin's delight in good company is also captured vividly in the documentary of his life, The Price of a Ticket. The film opens with Baldwin's funeral, a star-studded party if there was one. In attendance were friends, family, luminaries like Gwendolyn Brooks and Ishmael Reed. And throughout we learn the ways that Baldwin's friendships gird him for the struggles of his career's ups and downs.

7. Carmen Phelps's essay, "Living the Funk: Lifestyle, Lyricism, and Lessons in Modern and Contemporary Art of Black Women" is an important contribution to funk studies, in its naming of the role that "funkativity" plays in the aesthetics and lives of black women artists, including lesbian, bisexual, and queer women (in The Funk Era and Beyond: New Perspectives on Black Popular Culture, edited by Tony Bolden [New York: Palgrave, 2008], 182-91).

8. See Kevin Fellezs's book Birds of Fire: Jazz, Rock, Funk and the Creation of Fusion (Durham: Duke University Press, 2011) for more on the ways that gendered and generic divides in music seem to be mutually constituitive, particularly in the jazz world.

9. Rock writer legend Lester Bangs, no fan of disco, presents a similar vision of class and racial intermixture, though he presents it as weird and even sinister. He describes walking into a disco to find "Africans in a Spartan hat with a sprinkle seasoning of gays and white folks were just plain weird - nut bolt joiners off the factory line, lonely pubescent girls" (Everybody Dance: Chic and the Politics of Disco [London: Helter Skelter Publishing, 2004], xxii-xxiii).

10. For more discussion of the centrality of gay men of color in early disco scenes, see Tim Lawrence's important study Love Saves the Day: A History of American Dance Music Culture, 1970-1979 (Durham: Duke University Press, 2003), Bill Brewster and Frank Broughton's Last Night a DJ Saved My Life: The History of the Disc Jockey (New York: Grove Publishing, 2000), and Alice Echols's Hot Stuff: Disco and the Remaking of American Culture (New York: W. W. Norton, 2010). Of these three studies, Echols's is the only one to pay significant attention to the contribution of women, and in particular black women, in disco's sounds and aesthetic, as well as consumption.

11. Labelle has also collaborated with white women, performing with Bette Midler (who calls herself "the white Patti LaBelle") and Laura Nyro. In Mark Anthony Neal's excellent Songs in the Key of Black Life: A Rhythm and Blues Nation (New York: Routledge, 2003), he analyzes Labelle's role on Laura Nyro's salute to girl groups, Gonna Take a Miracle (1971). As Neal points out, this collaboration fruitfully heightens the feminist and queer implications of the lyrics, giving them a rereading — in part through the album's very self-conscious approach to the politics of black and white women's voices and the sharing of space, of the ways that we read this music as white and black women collaborating. Gonna Take a Miracle becomes a site for friendship and personal support, a way to survive the music industry for Patti and Nyro. (This is discussed more in chapter 25 of Patti LaBelle's Don't Block the Blessings [New York: Riverhead Books, 1996].) 
12. Here I'm drawing on Mark Anthony Neal's persuasive description of the gospel aesthetic of "drive" or "working sections" in Labelle's sound, in his analysis of the Nyro-Labelle collaboration, Gonna Take a Miracle. Neal quotes gospel historian Ray Allen, who defines "drive" or "working sections" as "segments of chanted and sung improvisation . . . a drive section begins when the instrumentalists stall on one chord while background singers repeat a single vocal line over and over. At this point the lead singer begins to ad lib, switching from his or her regular singing voice into a terse, high pitched, rhythmically repetitive chant or singing chant" (quoted in Neal, 2003, 88-89). This "drive" is a moment of heightened emotionality and a place to make strong personal and spiritual connection with their audience. In Neal's analysis of the collaboration between Labelle and Laura Nyro, in the song "Nowhere to Run," the drive section comes in the place toward the end of the song, where the line "Nowhere to Run" is repeated and then exchanged between Nyro and Labelle. Their reads of the line, Neal hears the specificity of black and white women's experiences, their distinct experiences of patriarchy, and particularly, the ways that black women are both affected by race and class. As Nyro follows Labelle, we find her reading of the line shifts, reflecting how she is taught by the aural analysis provided by Labelle. So the "drive" section, "within this moment of 'Spirit induced joy' or 'Gospel frenzy,' Nyro and Labelle create a space for feminist catharsis, notably within the context of black feminist or womanist spiritual practices" (Neal, 2003, 89).

13. This is confirmed by a recent posting on YouTube in response to a video performance of a song - a 2008 reunion performance on BET: "It appeals to the church boy in me but also makes me want to 'twirl' like I used to do years ago in the club. LOVE IT!!!!!" Labelle has an active YouTube fan life, and even songs without video get regular, enthusiastic postings from old and new fans.

\section{Works Cited}

Bell, Derrick. Gospel Choirs. New York: Basic Books, 1996.

Brewster, Bill, and Frank Broughton, Last Night a DJ Saved My Life: The History of the Disc Jockey. New York: Grove Publishing, 2000.

Crazy Horse, Kandia. "Space Oddities." Offbeat (July 2008): 26-28.

Dery, Mark. "Black to the Future: Afro-Futurism 1.0" (1995). http://www. detritus.net/contact/rumori/200211/0319.html.

Easlea, Darryl. Everybody Dance: Chic and the Politics of Disco. London: Helter Skelter Publishing, 2004.

Echols, Alice. Hot Stuff: Disco and the Remaking of American Culture. New York: W. W. Norton, 2010.

Edwards, Henry. "The Street People Are Taking over the Discotheques!" High Fidelity 25 (July 1975): 56-58.

Fellezs, Kevin. Birds of Fire: Jazz, Rock, Funk and the Creation of Fusion. Durham: Duke University Press, 2011.

Garr, Gillian. She's a Rebel: The History of Women in Rock and Roll. New York: Seal Press, 1992, 2002.

Harris, Art. “Oh Baby It's Labelle.” Rolling Stone 190 (July 3, 1975): 42-46. Jackson, Buzzy. A Bad Woman Feeling Good: Blues and the Women Who Sing Them. New York: W. W. Norton, 2005.

Johnson, E. Patrick. "Feeling Spirit in the Dark: Expanding Notions of the Sacred in the African American Gay Community." Callaloo 21, no. 2 (spring 1998): 399-416.

LaBelle, Patti. Don't Block the Blessings. New York: Riverhead Books, 1996.

Lake, Steve. "Labelle_-Wow!" Melody Maker 50 (March 1975): 23.

Lawrence, Tim. Love Saves the Day: A History of American Dance Music Culture, 1970-1979. Durham: Duke University Press, 2003. 
Mahon, Maureen. "Black like This: Race, Generation and Rock in the PostCivil Rights Era." American Ethnologist 27, no. 2 (May 2000): 283-311.

Mahon, Maureen. The Right to Rock: The Black Rock Coalition and the Cultural Politics of Race. Durham: Duke University Press, 2004.

Morrison, Toni. Song of Solomon. New York: Vintage Books, 1977.

Muñoz, Jose Esteban. Cruising Utopia: The Then and There of Queer Futurity. New York: New York University Press, 2009.

Nathan, David. The Soulful Divas. New York: Billboard Books, 1999.

Neal, Mark Anthony. Songs in the Key of Black Life: A Rhythm and Blues Nation. New York: Routledge, 2003.

Nelson, Alondra. "Introduction: Future Texts." Social Text 20, no. 2 (summer 2002): 1-15.

Phelps, Carmen. "Living the Funk: Lifestyle, Lyricism, and Lessons in Modern and Contemporary Art of Black Women." In The Funk Era and Beyond: New Perspectives on Black Popular Culture, edited by Tony Bolden, 18291. New York: Palgrave, 2008.

Powers, Ann. "Labelle Was Always More than a 'Lady." Los Angeles Times (October 12, 2008): E2.

Royster, Francesca T. “'Here's a Chance to Dance Our Way Out of Our Constrictions': P-Funk's Black Masculinity and the Performance of Imaginative Freedom." In Sounding like a No-No: Queer Sounds and Eccentric Acts in the Post-Soul Era, 88-115. Ann Arbor: University of Michigan Press, 2013.

Unsigned. "Larry LeGaspi." In Sparkle Army. http://sparklearmy.com/blog/?tag=larrylegaspi.

Vincent, Rickey. Funk: The Music, the People and the Rhythm of the One. New York: St. Martin's Press, 1996. 